\title{
Australian court decision on passive smoking upheld on appeal
}

\author{
Simon Chapman, Stephen Woodward
}

The Australian tobacco industry has been on the very sick list for at least the past 16 years, with adult per capita consumption falling by about one third to its present annual level of 1827 grams. Since 1983, the year when the first of a series of large scale mass media campaigns started ${ }^{1}$ and the momentum against tobacco advertising and smoking in the workplace increased, the average annual fall has been $2 \cdot 54 \% .^{2}$ Rothmans, the perennial market leader, saw its share price fall from $\$ \mathrm{~A} 14 \cdot 10$ to $\$ \mathrm{~A} 4 \cdot 70$ during the past year, wiping $\$ A 1 \cdot 1$ billion off its market capitalisation. But the Christmas of 1992 may be remembered by the Australian tobacco industry as one of its bleakest ever. On 17 December its officials woke to radio bulletins announcing that a bill to ban all remaining forms of tobacco advertising had, in the small hours, finally passed through both houses of the federal parliament with the support of all parties. Tobacco advertising through sponsorship and billboards had been waiting like the last prisoners on death row for eight months following a cabinet announcement in April 1992 that the end of their last ditch stand was nigh. (Grand prix car and motorcycle racing is to be exempted. The brands involved in sponsoring grand prix (Marlboro, Camel, Gitanes, Lucky Strike, and Rothmans) each have minute brand shares in Australia, but, unlike France, which has recently lost its place on the grand prix circuit because of its refusal to allow tobacco advertising, Australia will continue to "export" these images around the world in race telecasts.)

In late November a stay of execution seemed possible when some rodeo interests in north Queensland successfully lobbied the Labor caucus, arguing that the ban would mean destitution for this icon of Australian bush spirit, traditionally sponsored by tobacco. Then the thousand or so readers of a few imported fashion magazines (which it seemed would be prohibited because they contained foreign tobacco advertisements) momentarily rallied key support from the free speech lobby. Both of these hiccups were rapidly suppressed by amendments involving hardship clause replacement money and blind eye exemptions for minor transgressions like the trickle of foreign magazines. The bill will see all remaining forms of tobacco advertising phased out by the end of 1995 . The Benson and Hedges cricket competition will then be no more; the increasingly national rugby league competition will probably be taken over by a beer, cola, telecommunications, or insurance sponsor.

Not two hours after digesting this news over their breakfasts, the same industry officials made their way to the Federal Court of Australia to receive the decision on their appeal over the February 1991 judgment by Justice Morling on a Tobacco Institute of Australia advertisement concerning passive smoking that was run throughout the Australian press in 1986. Justice Morling had ruled in favour of a suit filed by the Australian Federation of Consumer Organisations that the advertisement was misleading and deceptive, breaching a section of the Trade Practices Act. ${ }^{3}$ The Morling judgment centred on a sentence within the advertisement that stated: "And yet there is little evidence and nothing which proves scientifically that cigarette smoke causes disease in non-smokers."

Justice Morling's judgment determined that the statement was indeed misleading and deceptive. The judge made orders that restrained the Tobacco Institute of Australia from further publishing the advertisement and from making a number of statements based on the sentence cited above. He also ordered that costs be paid to the Australian Federation of Consumer Organisations on an indemnity basis. Estimates of the costs involved in the conduct of both parties' cases, which involved evidence being taken in Sydney and London over 91 days, plus 15 days in the appeal, are put at $\$ \mathrm{~A} 10$ million. The decision in the case was seen as having considerable worldwide significance and the Tobacco Institute of Australia immediately appealed against all the major findings of the judgment.

\section{Results of the appeal}

The appeal was heard by three judges of the Federal Court, Justices Shepherd, Foster, and Hill. We consider the main findings and some of the more interesting arguments advanced by the judges in their 148 page judgment.

Of utmost significance was that all three judges upheld the finding that the critical sentence in the advertisement was misleading and deceptive and therefore was in breach of the Trade Practices Act. The judges declined to accept the Tobacco Institute of Australia's argument that the sentence was not intended as a statement of fact but as merely an expression of opinion or as the platform of an argument in a community wide debate.

Each judge was emphatic that Justice Morling's decision and that reached by them on appeal rested on a consideration of the context and the wording of the claim that there was "little evidence" and "nothing which proves scientifically" that cigarette smoke causes disease in non-smokers. Much of each judgment was taken up with painstaking reviews of the historical and social context of the advertisement's publication, with the syntactical features of the sentence and its relationship to the rest of the advertisement, and with the undeniable fact that indeed there was considerable "evidence" about the matters at hand at the time of the advertisement's publication.

Justice Shepherd emphasised that regarding the placement of the advertisement with its claims in the press, there needed to be an appreciation that it would be "read by the intelligent and the wary and also by the unsuspecting, the gullible, and the impressionable." He stated that "it ought to be inferred that... one of the purposes of the advertisement was to enable it to be used by smokers as ammunition to persuade others that their habit was not dangerous to the health of anyone except perhaps their own." He concluded that "the meaning which the advertiser intended to convey was that there was not a thing, not a jot and not a tittle, which would prove scientifically that cigarette smoke caused disease." Like his colleagues, Justice Shepherd vehemently rejected this imputation in upholding Justice Morling's principal decision.

However, the appeal judges were critical of Justice Morling's willingness to enter into an assessment of the quality of the epidemiological evidence tendered by both parties, and of his comments about his 


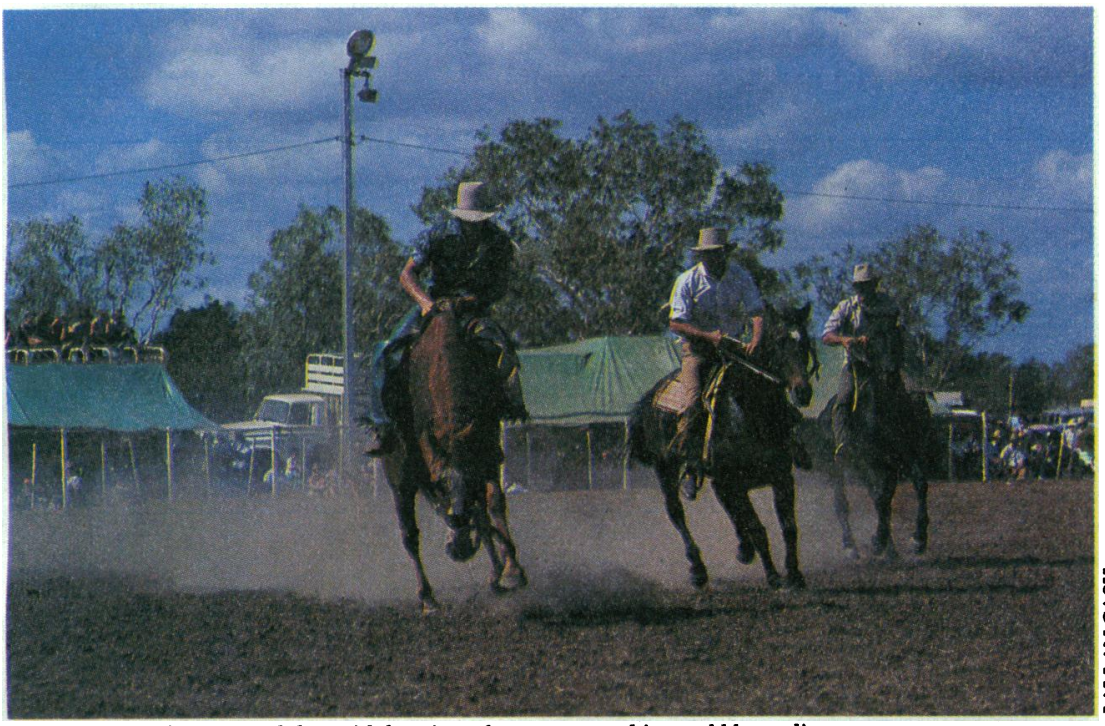

Australian cowboys argued that withdrawing tobacco sponsorship would have dire consequences

preferences for particular epidemiological evidence and witnesses. Justice Foster said of the discordance between the evidence of the epidemiological witnesses called by the Australian Federation of Consumer Organisations and the Tobacco Institute of Australia, "It was not a disagreement which the learned primary judge or this Court could reasonably resolve." He concluded, "The matter... falls for determination not on the basis of accuracy, validity, or acceptability of the scientific evidence or aspects of it, but simply upon its existence."

The judges thus concluded that detailed excursions into the epidemiological evidence were by and large immaterial to the matter at hand: the question of whether there was deception involved in the statement that there was "little evidence" and the imputations arising from this statement for the general thrust of meaning in the advertisement as a whole. Of epidemiology, Justice Shepherd said, "Despite its inexactitude epidemiology is a science" and that "epidemiological studies... cannot be dismissed as "nothing'." The word "nothing" in the advertisement was thus critical to the determination that deception had occurred.

For the Australian Federation of Consumer Organisations to succeed in its suit, it needed to establish that the Tobacco Institute of Australia's advertisement "was published in trade or commerce." The three appeal judges considered this issue at length and, again, all affirmed Justice Morling's decision that the advertisement was rightfully to be considered as being published for the commercial gain of the tobacco industry. Justice Foster concluded that the advertisement "create[d] an irresistible impression that it was promotional material designed to advance the cause of cigarette smoking and to assist in the sale of cigarettes." Of the relationship between the Tobacco Institute of Australia (which itself does not manufacture or retail tobacco) and the tobacco industry, which supports and directs its staff and their activities, Justice Foster concluded, "There can be no doubt that a corporation, formed to promote the interests of a particular industry... acts 'in trade or commerce' when conveying representations about that industry's product to the general public." The implications of this statement will doubtless resonate throughout many an industry in the years to come.

The judges handed the Tobacco Institute of Australia something of a pyrrhic victory when they said they would set aside Justice Morling's injunction on the further publication of the advertisement on the legalistic basis that the Tobacco Institute of Australia had previously indicated to the Australian Federation of Consumer Organisations that it would not republish the advertisement anyway.

The judges also said that they would set aside the orders of Justice Morling that the Tobacco Institute of Australia could never, at any time in the future, replicate the claims contained in the offending sentence. They argued that scientific progress and understanding could not be conceived of as a static process; with the advance of research into passive smoking, different conclusions might one day become apparent.

In summary, then, the Tobacco Institute of Australia was found guilty of publishing a misleading and deceptive advertisement. It was also handed a symbolic but fairly meaningless victory in having two orders varied. These concerned matters that were a pure technicality (being allowed to run an advertisement that it would have had no intention of ever running again) and a virtual truism (being told that future circumstances may arise in which it should be reasonably able to readdress the issues at hand).

But perhaps this interpretation is rather too literal. Significantly, at press conferences after the judgment both sides claimed the result as a resounding victory. In terms of a public health perspective, the decision certainly rubbed salt into the tobacco industry's already gaping wounds. At its core was very bad news: it remains true that the Tobacco Institute of Australia was guilty in 1986 of misleading and deceiving the Australian public about the existence of evidence which might (according to many) be reasonably said to prove that passive smoking was harmful. Smoking control advocates will thus be justified in broadcasting that the tobacco industry is (yet again) on the public record as having been shown to be deceitful in its communications with the public. Doubtless there will be many highly strategic opportunities where this humiliation will be fully exploited.

But the tobacco industry is unrivalled at making silk purses from sows' ears. It still maintains with blithe equanimity its opinion that active smoking, let alone passive smoking, does not cause disease-it has been shown only to have a "statistical association," much in the same way that sexual intercourse might be denied to "cause" pregnancy. This is in spite of the scientific advisory committee of its own research foundation having made a unanimous public statement that it believes smoking is a causative factor in several major diseases. ${ }^{4}$ The many pages of detailed argument in this judgment about the plurality and inexactitude of scientific consensus generally, and of epidemiology in particular, will provide the Houdinis in the industry's public relations sections with a feast of prestigious quotations and one liners. These will ably assist with the perpetuation of the "more research is needed" rhetoric that has become the industry's public mantra. ${ }^{56}$

The passive smoking issue holds enormous fears for the tobacco industry. ${ }^{7}$ The champagne went down very well on the night the Tobacco Institute of Australia's appeal substantially failed, but we fear that the hangover from this report may last rather longer. In the 148 pages of this judgment lies quite priceless advice to the industry about how it might become more clever in the same ambitions that gave birth to this clumsily worded advertisement. Each judge offers advice, often explicit, on how the offending sentence could have been published without falling prey to a misleading and deceptive charge. For example, Justice Foster said, "Had the author [of the advertisement] wished to indicate that nothing more than an opinion was being expressed, he could have achieved this object quite simply by introducing the very same words 'we think' before the 'there is little evidence'." Such passages to us seem prophetic of industry tactics we are likely to see in the 1990s. If the Tobacco Institute of Australia is required to pay the Australian Federation of Consumer 
Organisations \$A1.5 million when costs are determined, it may well consider the experience to have been money well spent. It has received meticulous counsel from one of the nation's highest courts about what it might wish to say on the subject in the future. Equally, though, we would prefer to think that the Australian Federation of Consumer Organisations's experience will inspire other Davids of the tobacco control world to stone the lumbering Goliath of the tobacco industry with ever increasing legal and tactical accuracy.

We acknowledge the assistance in ensuring the legalistic accuracy of this paper provided by Neil Francey, barrister at law, who was the counsel appearing for the Australian Federation of Consumer Organisations before Justice Morling at the first instance and for the full Federal Court appeal
Copies of the appeal judgment are available for research purposes for $\$ A 20$ postage paid from Stephen Woodward at the address given.

1 Macaskill P, Pierce JP, Simpson JM, Lyle DM. Mass media-led antismoking campaign can remove the education gap in quitting behaviour. Am f Public Health 1992;82:96-8.

2 Department of Community Services and Health. Tobacco in Australia. A summary of related statistics. Canberra: Australian Government Publishing Service, 1990:12.

3 Chapman S, Woodward S. Australian court rules that passive smoking causes lung cancer, asthma attacks and respiratory disease. $B M \mathcal{F}$ 1991;302:943-5.

Doyle AE, Rand M, Powell LW, Simmonds W, Wing I, Zylstra W. The Australian Tobacco Research Foundation. Med f Aust 1988:148:152.

Chapman S. Tobacco industry health resch "blood money": the Brith .

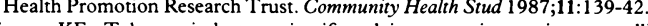

Warner Ke. Tobacco industry scientific advisors: serving society or selling

7 Chapman S, Borland R, Hill D, Owen N, Woodward S. Why the tobacco industry fears the passive smoking issue. Int $f$ Health Services 1990;20

(Accepted 21 December 1992)

\title{
Alternative allergy and the General Medical Council
}

\author{
A B Kay
}

In July 1992 Dr Keith Mumby, a clinical ecologist, appeared before the professional conduct committee of the General Medical Council on five charges to do with his practice of clinical ecology. He was found guilty of two of the charges-touting for publicity and failing to give a patient adequate medical attention-and admonished. The GMC failed, however, to address the issue of the nature of Mumby's treatments-clinical ecology itself. This is based on the idea that some patients are unusually susceptible to their environment, the diagnosis and treatment are based on an unstandardised provocation-neutralisation test. A variety of medical bodies have failed to find scientific foundation for the technique. The GMC's policy on advertising services to patients is inconsistent, and in this case it has shown a regrettable reluctance to deal with the issue of treatments that are not scientifically validated.

In July 1992 the General Medical Council's professional conduct committee considered the case of $\mathrm{Dr}$ Keith Mumby, a clinical ecologist. The GMC called me as an expert witness. In the event my evidence-on the scientific value of clinical ecology - played little part in the proceedings because the charges brought by the GMC touched only peripherally on Dr Mumby's clinical activities. I describe the proceedings here, however, because they raise questions about the willingness of the GMC to protect patients from forms of diagnosis and treatments which have not been sufficiently validated and about its lenient attitude to a doctor who persistently touted for business by attracting the interest of tabloid journalists.

\section{The Mumby case}

Dr Keith Mumby graduated from Manchester University in 1971 . He did his preregistration year and a year of vocational training in general practice but then stopped working as a doctor until he opened an allergy clinic in 1982. Since then he has been featured in many newspaper articles. Highlights include "Allergy plight of nice-girl Nicky-'one sip of vodka turns me into a sex maniac" (News of the World magazine) and "Women could be turned on by a chunk of cheddar" (People).'

$\mathrm{He}$ had been arraigned before the GMC twice before, both times for canvassing. In 1982 he was found guilty of serious professional misconduct and undertook not to let it happen again. In 1987 he was found not guilty over a full page article in the Sunday Express. Dr Mumby has been the target of investigative journalism at least three times; the last of these, an article in Scotland on Sunday in $1991,{ }^{2}$ resulted in this year's GMC hearing.

On 13 July Dr Mumby appeared before the GMC's professional conduct committee charged:

(1) that he touted for patients using a publicity agent;

(2) that he caused avoidable distress by giving injections (as tests or treatment or both) in front of other patients and members of the public;

(3) that he gave the names of two patients to journalists without first seeking their permission;

(4) that he treated Ian Royan without taking a proper history or examination, or first contacting his general practitioner; and

(5) that he injected Royan with a substance he knew would harm him, in the presence of the press, and failed to given him adequate medical attention.

Dr Mumby was found guilty of only the first and last charges, for which he was admonished.

The evidence for charge 1 included a letter from Dr Mumby in August 1987 to his "publicity agent," freelance journalist Brian Whittle:

\section{Dear Brian,}

Herewith the letter from Mrs Massey. I think you will agree it's got the beginnings of a nice story. To re-emphasise, I would like this one played a little bit special if you can. Try to get it as a "Dr Mumby does it again", not just a patient story. The effect from the Sunday Express article is just beginning to wane slightly and a boost now would be absolutely terrific and see us right through to Christmas.

Dr Mumby said that the letter had been stolen and was therefore inadmissible, and that it was written in jest. Whittle agreed that it was a typical Mumby joke.

Dr Mumby successfully defended himself against causing distress by performing allergy tests in front of others and of giving patients' names to the press. Several witnesses, including other patients and $\mathrm{Dr}$ Mumby's staff, said that patients generally welcomed company during skin testing sessions, and all three expert witnesses (myself, Professor Anne Ferguson for the GMC, and Dr Jonathan Brostoff for the defence)
Institute, London

A B Kay, director

BMF 1993;306:122-4 